\title{
A NEW ARTIFICIAL REEF DESIGN FOR OCTOPUS (Octopus vulgaris CUVIER, 1797) IN THE AEGEAN SEA AND PRELIMINARY RESULTS*
}

\author{
Ali Ulaş**, Altan Lök, F. Ozan Düzbastılar, Aytaç Özgül and Cengiz, Metin \\ Faculty of Fisheries, Aegean University \\ Ege University Faculty of Fisheries, Dept. of Fishing and Processing Technology
}

(35100 Bornova, İzmir, Turkey)

**Corresponding author: asulas@yahoo.com

\section{A B S T R A C T}

This study was carried out in the Gulf of İzmir in the Aegean Sea between June 2006 and November 2008. The purpose was the creation of a new concept of the artificial reef for Octopus vulgaris, with a view to establishing new artificial reef sites to be used in the fisheries management of this species (MPA, NTZ or fishing areas). First, the main characteristics of natural octopus nests were recorded (entrance width, length, etc.) by divers. These characteristics were used in the construction of new octahedral artificial reef blocks. The blocks were made of reinforced concrete, in a shape like that of an inverted pyramid, with an upper surface of 100x100x25 $\mathrm{cm}^{3}$ and a lower one of $60 \times 60 \mathrm{~cm}^{2}$. Four cylindrical holes each with two ellipsoidal openings were placed in one face and in the lateral edge of the octo-block, to serve as the entrances to the artificial nest. Each nest has a volume of $5000 \mathrm{~cm}^{3}$. Eighty octo-blocks were deployed as artificial reefs at $10 \mathrm{~m}$ from each other at 15 different depths at two sites by divers with the help of the winch of the R/V EGESUF. These artificial octo-reefs were censused by direct observation. Twenty-eight octopuses were sampled at the end of 25 dives. Minimum mantle length of the octopuses was $75 \mathrm{~mm}$ and the maximum $249 \mathrm{~mm}$, with an average of $152.71 \mathrm{~mm}$. The average total length was calculated to be $918.57 \mathrm{~mm}$. The weight of the specimens was between $244 \mathrm{~g}$ and $7140 \mathrm{~g}$ with an average of $2335.43 \mathrm{~g}$. The results showed that both sites were inhabited by octopuses coming from the artificial reefs, which used them as nests. These nests seem to have constituted special places for fisheries management and will permit the assessment of reserve areas or marine protection areas (MPA), thus opening up a new perspective for Turkish fisheries.

\section{RESUMO}

Este estudo foi realizado no golfo de İzmir, no Mar Egeu, entre junho de 2006 e novembro de 2008. O objetivo foi uma nova concepção de recife artificial para Octopus vulgaris, visando o estabelecimento de novos locais a serem utilizados na gestão da pesca dessa espécie (MPA, NTZ ou zonas de pesca). Primeiramente foram consideradas as principais características dos ninhos naturais do polvo (largura da entrada, comprimento, etc.). A seguir essas características foram utilizadas na construção de novos blocos octaédricos de recifes artificiais. Os blocos foram feitos de concreto armado, assemelhando-se a uma pirâmide invertida, nas dimensões de $100 \times 100 \times 25 \mathrm{~cm}^{3}$ na face superior e $60 \times 60 \mathrm{~cm}^{2}$ na face inferior. Quatro furos cilíndricos, com duas aberturas elipsoidais, foram dispostos em uma só face e na borda lateral do octo-bloco, correspondendo às entradas do ninho artificial. Cada ninho tem um volume de $5000 \mathrm{~cm}^{3}$. Foram implantados 80 octo-blocos para servirem como recifes artificiais, guardando a distância de $10 \mathrm{~m}$ entre si, em 15 profundidades e em dois locais diferentes, com auxílio de mergulhadores e guincho do R/ V EGESUF. Esses recifes foram recenseados, utilizando-se o método de observação direta. Vinte e oito polvos foram amostrados ao final de 25 mergulhos. O comprimento mínimo do manto do polvo foi de $75 \mathrm{~mm}$ e o máximo de 249 $\mathrm{mm}$, com média de $152,71 \mathrm{~mm}$. O comprimento médio total foi determinado em $918,57 \mathrm{~mm}$. O peso dos espécimes ficou entre 244 e 7140 g, com média de 2335,43 g. Os resultados mostram que ambos os locais foram sustentados pelos polvos provenientes dos recifes artificiais, que os utilizaram como ninhos. Esses ninhos parecem constituir locais especiais para manejo da pesca, e permitirão a avaliação de áreas de reserva ou áreas marinhas de proteção (MPA), abrindo, desta forma, novas perspectivas para a pesca turca.

Descriptors: Octopus, Octopus vulgaris, Artificial Octo-reefs, Aegean Sea, Fisheries management (MPA: Marine protected area, NTZ: No Take ZoneZone).

Descritores: Polvo, Octopus vulgaris, Octo-recifes artificiais, Mar Egeu, Gestão da pesca (MPA: Área de Proteção Marinha, NTZ: Área de Restrição da Pesca). 


\section{INTRODUCTION}

The use of artificial reefs was first recorded in Japan in the last decade of the 17th century (MEIER, 1889). These early structures were used to replace other natural or man-made structures in response to the decline of fisheries in previously productive areas (CHRISTIAN et al., 1998). Artificial reefs have been used for many purposes such as increasing fish species and diversity, protecting sea meadows (GUILLEN et al., 1994) and creating new habitats for marine species (STEIMLE; ZETLIN, 2002). There are many studies related to species and reef characteristics (size and shape, material, number of holes, design, deployment depth etc.) (BROCK; NORRIS, 1989), however those on the possible designs of artificial reefs for the purpose of attracting target species are very few (NAKATA et al, 2001). Japanese literature reports that fish exhibit various tendencies as regards congregating at artificial reefs. Fish, according to one of these classifications, are identified as upper and middle layer swimmers, bottom layer swimmers and sedentary fish. The relation between the hard surface of reefs and their fish populations may be explained by some such physical parameters as shape, size, color, light, changes in currents, eddy, sound and reef material (GROVE, SONU, 1985). Japanese experts have emphasized that marine species other than fish show certain behavior patterns, abalone, sea urchin and lobster, for instance, preferring to settle on reefs and being sensitive to the shape of the blocks used (GROVE; SONU, 1985). During Japanese and other scientists' researches some species such as the nontarget species of sea urchin, lobster and octopus excepting fish - have been caught by fishermen or sampled by researchers (GROVE; SONU, 1985).

\section{Distribution and Behavior Patterns of Octopus}

Octopuses of this species occupy an important position both scientifically as regards the behavior of the octopus (MATHER, 1994) and economically in terms of fisheries (WHITAKER et al., 1991). A total of 289 species of octopus have been reported in the world's seas. $O$. vulgaris was previously believed to have worldwide distribution but is now only considered to occur in the Mediterranean and Eastern Atlantic (MANGOLD, 1997). A truly coastal species, it is found in the upper $100 \mathrm{~m}$ of the continental shelf, its abundance decreasing with depth (GUERRA, 1981). In the Mediterranean Sea, Eledone cirrosa, Eledone moschata, Octopus macropus and Octopus vulgaris are the most important species. They prefer various habitats such as rocky areas, muddy bottoms with nest blockage and man-made structures like wrecks, pipes and garbage etc (MANGOLD,
1983). Generally $O$. vulgaris choses particularly one direction holes (holes with only one outlet ?) and dark shelters, and constructs its nests using the shells and carapaces of crustaceans (FAO, 1973). It mostly prefers molluscs and crustaceans as food, sometimes fish. O. vulgaris is caught with spears with or without diving, pots, fishing lines and bottom trawls. Although it is of high commercial value and interest, catch statistics may not be fully correct due to the species' being evaluated together with the catches of fish and other cephalopod species caught with fishing gear. In spite of a lack of specific information, data show that the weight of octopus captured has decreased over the last five years both globally and in Turkish Seas. According to FAO statistics for 2004, the total octopus catches of the World and Turkey are 39,485 $\mathrm{t}$ and $1,185 \mathrm{t}$, respectively (FAO, 2004).

\section{Material ANd Method}

This project was carried out in the Gulf of Izmir in the Aegean Sea $\left(38^{\circ} 22 \mathrm{~N}--26^{\circ} 45 \mathrm{E}\right)$ between June 2006 and November 2008 (Fig. 1). Artificial reefs were constructed in order to protect and increase the population of the common octopus by way of creating new habitats. Field trials were conducted in three stages. First, the principal characteristics of natural octopus nests were recorded, including entrance width, length, volume, bottom type and water depth, by skin and scuba divers. Secondly, these characteristics were evaluated for the construction of new artificial octo-reef blocks.

The blocks were made of reinforced concrete to the dimensions: $100 \times 100 \times 25 \mathrm{~cm}$. They look like pyramids without their apex and inverted, stand on a $60 \times 60 \mathrm{~cm}$ square base. There is one hole in each side of the reef block, each of them thus facing in a different direction. The shape of the holes is similar to that of a cone whose apex has been cut off and whose entrance and base are thus of ellipsoidal shape ( $\varlimsup_{\text {entrance }} Æ 8 \mathrm{~cm}, \varlimsup_{\text {base }} Æ 13 \mathrm{~cm}$ ). Each hole has a volume of $5000 \mathrm{~cm}^{3}$ and the block weighs $286 \mathrm{~kg}$ (Fig. 2).

As a last stage in the construction of habitats for $O$. vulgaris, eighty reef blocks were deployed parallel to the shore at two different sites in the Gulf of Izmir, each reef thus consisting of forty units.

Reef blocks were deployed with the use of a winch and arranged by using lift ball to the deeper border of sea meadows. After the blocks had been arranged the visual census technique was used to determine and sample common octopus individuals and the camouflage they used in front of their artificial nests. Sea bottom temperature was measured over the period of a year with underwater temperature recorders. 


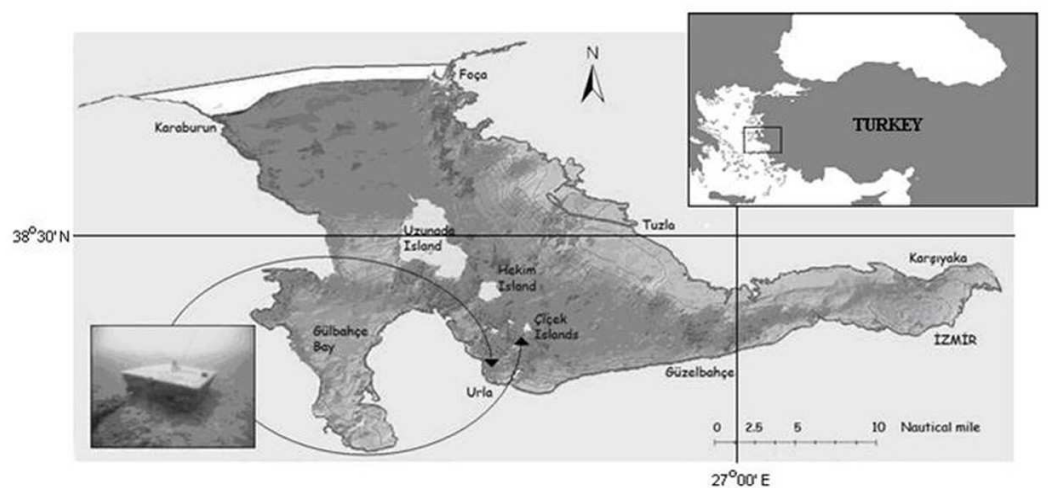

Fig. 1. Artificial reef sites and octo-reef unit (Drawing by courtesy of E. Yalçı).

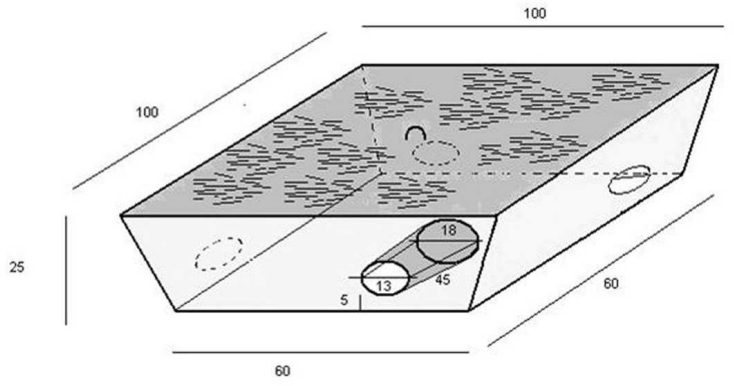

Fig. 2. Technical drawing of octo-reef block (measurements in $\mathrm{cm}$ ).

\section{RESULTS}

The Natural Characteristics of the Octopus's Nest

During the initial underwater observations the measurements of 168 natural octopus nests were taken and the measurements evaluated. The distribution of natural nests depends on bottom structure and depth. Rocky nests (75.61\%) are commonly found at 0 to 10 meter depths, muddy nests $(13.41 \%)$ at depths greater than $10 \mathrm{~m}$ and sandy nests $(10.98 \%)$ between 0 and $7 \mathrm{~m}$. Some criteria were analyzed, especially regarding the natural nest's entrance width and its length, which have been shown to be important in the design of artificial reefs. As for the shape and width of the nest's entrance, the average of the ellipsoidal width was found to be $13.36 \pm 3.2 \mathrm{~cm}$. The nests in artificial reefs are designed in accord with that finding, and ellipsoidal entrances as wide as 13 $\mathrm{cm}$ and as small as $8 \mathrm{~cm}$ in diameter are produced. The width of the entrance of the nests was designed to be narrower than their depth. The average length of natural nests was found, by the underwater observations, to be $30.86 \pm 8.03 \mathrm{~cm}$. Thus the nests in the octo-reef blocks were built to be $40 \mathrm{~cm}$ in length (with an approximate volume of $5000 \mathrm{~cm}^{3}$ ). Generally, in nature, the octopus prefers pots or jugs as a nest, just as it has been observed to do. Octo-reef blocks are made of reinforced concrete and nest parts are made of a kind of curved tiles (Fig. 3).

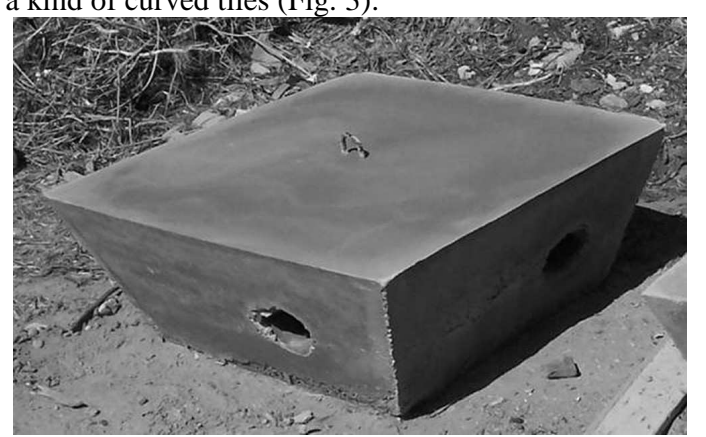

Fig. 3. Octo-reef block

Biometric data of Octopus in Artificial Octo-reefs

The octopus reefs were investigated by census, using the direct observation method. Twenty- 
eight octopuses were sampled during 25 dives. Sea bottom temperature was measured over a one-year period (min. $12^{\circ} \mathrm{C}$ in January, max. $25^{\circ} \mathrm{C}$ in August). Octopus sampling temperature was determined as between $13.1 \mathrm{C}^{\circ}$ and $19.4 \mathrm{C}^{\circ}$. Minimum mantle length of octopus was $75 \mathrm{~mm}$ and maximum $249 \mathrm{~mm}$, the average being $152.71 \mathrm{~mm}$. The average total length was calculated at $918.57 \mathrm{~mm}$. Minimum and maximum weights of octopus were, respectively, 244 $\mathrm{g}$ and $7140 \mathrm{~g}$, the average being $2335.43 \mathrm{~g}$. The mantle length-weight relationship is given in Figure 4. Regression was found to be 0.7 because of the octopus's flexible and changeable body shape. The female/male sex ratio found was 1:3.

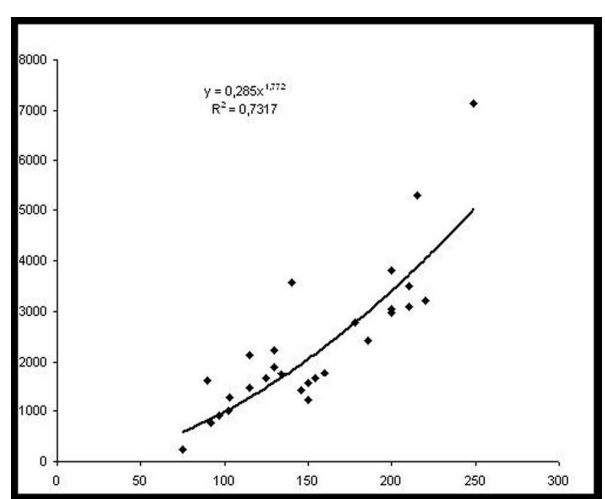

Fig. 4. Mantle length-weight relationship of $O$. vulgaris in Octo-reef.

During the sampling dives, some shells and carapaces were observed in front of octo-reef blocks. The species concerned composed the diet of $O$. vulgaris at the artificial reef sites (Table 1). This information shows that 25 artificial nests were used by octopuses in the octo-reefs.

\section{Discussion}

The octopus is a habitat-related creature; its nest is a vital choice for an octopus. The choice of a nest is not made at random, certain nest characteristics are extremely important for survival. These characteristics are entrance width, entrance position and nest volume. Moonoosamy (2008) comments that artificial nests with wide openings seemed to be unpopular with the occupants as they seemed rather unsafe for octopus. In the artificial nests he designed for octopus, their openings were kept small (the diameter is of about 6 to $8 \mathrm{~cm}$ ). Ebata (2007) created octopus pots for spawning and as adult shelters. He explains that the pot's entrance $(12 \mathrm{~cm}$ diameter) must be narrower than its interior. Ulaş (2001) states that thirty artificial octo-reef blocks were deployed in Izmir bay but that there was no evidence of occupation by octopus during the two years since their deployment due to the nests' opening being too large $(18 \mathrm{~cm})$. Katayama (1996) designed artificial reefs for the common octopus to provide an artificial fish reef to create an environment suitable for its growth and life from spawning onwards. He used a $12 \mathrm{~cm}$ entrance opening in the artificial octopus nest. Artificial reef sites were selected according to bottom type. Sea meadows ended at $15 \mathrm{~m}$ depth in İzmir bay. These sites contained the bivalve and gastropod species which are part of the octopus's diet and for this reason artificial reef sites were selected at $15 \mathrm{~m}$ depth. During the sampling period, 14 species of bivalve, 1 species of gastropod and 1 species of crustacean were observed in front of the artificial octo-reefs.

Table 1. Food preferences of $O$. vulgaris at the artificial reef sites.

\begin{tabular}{|c|c|c|}
\hline & OSTREIDAE & Ostrea edulis L. 1758 \\
\hline \multirow{13}{*}{ BIVALVIA } & & Venus verrucosa L. 1758 \\
\hline & & Venus gallina L. 1758 \\
\hline & VENERIDAE & Callista chione L. 1758 \\
\hline & SOLECURTIDAE & Solecurtus srtigillatus L. 1758 \\
\hline & GLYCYMERIDIDAE & Glycymeris bimaculata P. 1795 \\
\hline & & Glycymeris violacescens L. 1819 \\
\hline & LIMIDAE & Lima tuberculata O. 1792 \\
\hline & PECTINIDAE & Munupecten pesfelis L. 1758 \\
\hline & & Pecten jacobaeus L. 1758 \\
\hline & & Chlamys varia L. 1758 \\
\hline & MYTILIDAE & Mytilus galloprovincialis Lam 1819 \\
\hline & ARCIDAE & Arca noae L. 1758 \\
\hline & PINNIDAE & Pina nobilis L. 1758 \\
\hline GASTROPODA & HALIOTIDAE & Haliotis tuberculata. L. 1758 \\
\hline CRUSTACEA & MAJIDAE & Maja squinado H. 1788 \\
\hline
\end{tabular}


Results have shown that artificial octo-reef sites ensure replenishment of stocks and protect the species, thus enabling them to attain productive adult size. Adult octopus signifies spawning and larvae production. Fishermen were attributed a limited number of octopus habitats so as to maintain low, sustainable catch per unit effort. These artificial octopus nests were to be used strictly in the fishing ground and only after consultation with the local fishermen.

\section{Conclusion}

The principal objective of the project was the creation of a new artificial reef design for Octopus vulgaris, and its deployment. Despite illegal fishing pressure, twenty-eight individuals were observed and sampled at the reef sites. (Fig. 5) Particularly, $O$. vulgaris individuals prefer to live alone and beside the sea meadows in the proximity of the reef.

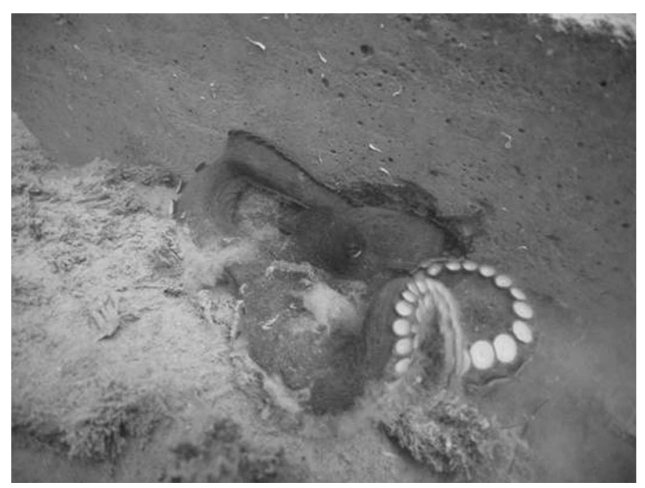

Fig. 5. O. vulgaris in artificial octo-reef.

In terms of preliminary evaluation, the average weight of the specimens was calculated at 2335.43 g., above the legal catch size (1000 g.) This demonstrates that the new artificial reef design is appropriate for $O$. vulgaris. The reef site censuses and measurements will continue in subsequent studies in order to confirm this evidence. The preference for and use of the artificial octo-reefs by octopuses is a scientific innovation and this is the first study of a species specific application in Turkey.

\section{REFERENCES}

BROCK, R. E.; NORRIS, J. E. An analysis of the efficacy of four artificial reef designs in tropical waters. Bull. mar. Sci., v. 44, n. 2, p. 934-941, 1989

CRISTIAN, R.; STEIMLE, F.; STONE, R. Evolution of marine artificial reef development-A philosophical review of management strategies. Gulf Mexico Sci., v.16, n.1, p. 32-36, 1988.

EBATA, K. Observation of the spawning pot of octopus in Kagoshima Bay. In: PASCHEN, M. (Ed.). Contributions on the theory of fishing gears and related marine system. Aachen: 2007 . V. 5, p. 141147.

FAO. Species identification sheets for fishery purposes (Mediterranean and Black Sea). FISCHER, W. (Ed.). Rome, 1973

FAO. Fisheries global information system, FIGIS. Global production statistics (1950-2004). Rome, 2004.

GROVE, R. S.; SONU, C. J. Fishing reef planning in Japan. In: D'ITRI, F. M. (Ed.). Artificial reefs. Michigan: Lewis Publishers, 1985. p. 187-249.

GUERRA, A. Spatial distribution pattern of Octopus vulgaris, 1981. J. Zool. London, v. 195, p. 133-146, 1981.

GUILLEN, J. E.; RAMOS A. A.; MARTINEZ, L.; LIZASO, J. L. S. Antitrawling reefs and the protection of posidonia oceanica (L) Delile meadows in the Western Mediterranean Sea: demands and aims. Bull. mar. Sci., v. 55: n. 2-3, p. 645-650, 1994.

KATAYAMA, K. Artificial fish reef for common Octopus. Patent Abstracts of Japan, Mar 1996, patno:JP1996080139

MANGOLD, K. Octopus vulgaris In: BOYLE, P.R. (Ed.). Cephalopod life cycles. V. 1. London: Academic Press, 1983. p. $335-364$

MANGOLD, K. Octopus vulgaris: Review of the biology. I. LANG, M.A; HOCBERG, F.G. (Ed.). THE FIRST WORKSHOP ON THE FISHERY AND MARKET POTENTIAL OF OCTOPUS IN CALIFORNIA, Smithsonian Institution, Washington, 1997. Proceedings ... p. 85-90, 1997.

MATHER, J. A. Home choice and modification by juvenile Octopus vulgaris (Mollusca: Cephalopoda): specialized intelligence and tool use? J. Zool.2 Lond., v. 233, p. 359368, 1994.

MEIER, M. H. A debate on responsible artificial reef development. part 1: in support of public and private sector artificial reef building. Bull. mar. Sci., v. 44, n. 2 , p. 1051-1057, 1989.

MOONOOSAMY, K.; NARRAINEN, S.; BEEHARY PANRAY, R. D. The Re-construction of artificial reefs for octopus using discarded electric poles. Cheltenham, England: International Association for the Study of the Commons, 2008.

NAKATA, K; HAMANO, T.; HAYASHI, K-I.; KAWAI, T. Artificial burrow preference by the Japanese crayfish Cambarodies japonicus. Fish. Sci., v. 67, p. 449-455, 2001.

STEIMLE, F. W.; ZETLIN, C. Reef habitats in the Middle Atlantic Bight: abundance, distribution, associated biological communities and fishery resource use. Mar. Fish. Rev., v. 62, n. 2, p. 24-42, 2000.

ULAŞ, A. A study on natural and artificial habitat of Octopus (Octopus vulgaris Cuvier, 1797) population in Gulf of Izmir. 2001. 72 p. Ph.D. Thesis, Aegean University Natural and Applied Sciensenst. Bornova Izmir, 2001.

WHITAKER, J. D.; DELANCEY, L. B.; JENKINS, J.E. Aspects of the biology and fishery potential for Octopus vulgaris off the coast of South Carolina. Bull. mar. Sci., v. 49, n. 1-2, 482-493, 1991.

(Manuscript received 07 March 2010; revised 08 March 2011; accepted 15 March 2011) 